\title{
Pyrroloquinoline Quinone Prevents Oxidative Stress-Induced Neuronal Death Probably through Changes in Oxidative Status of DJ-1
}

\author{
Kana Nunome, ${ }^{a}$ Shin MiYazAKI,${ }^{a}$ Masahiko NaKano, ${ }^{b}$ Sanae IGUCHI-ARIGA, ${ }^{c}$ and \\ Hiroyoshi ArIGA*,a \\ ${ }^{a}$ Graduate School of Pharmaceutical Sciences, Hokkaido University; ${ }^{c}$ Graduate School of Agriculture, Hokkaido \\ University; Kita-ku, Sapporo 060-8589, Japan: and ${ }^{b}$ Mitsubishi Gas Chemical Co., Inc., Niigata Research Laboratory; \\ Kita-ku, Niigata 950-3112, Japan. Received March 22, 2008; accepted May 1, 2008; published online May 2, 2008
}

\begin{abstract}
Pyrroloquinoline quinone (PQQ) has been shown to play a role as an anti-oxidant in neuronal cells and prevent neuronal cell death in a rodent stroke model. DJ-1, a causative gene product for a familial form of Parkinson's disease, plays a role in anti-oxidative stress function by self-oxidation of DJ-1. In this study, the expression level and oxidation status of DJ-1 were examined in SHSY-5Y cells and primary cultured neurons treated with 6hydroxydopamine (6-OHDA) or $\mathrm{H}_{2} \mathrm{O}_{2}$ in the presence or absence of PQQ. The pI shift of DJ-1 to an acidic point, which was observed in SHSY-5Y cells treated with 6-OHDA, was inhibited by PQQ. TOF-MS analyses showed that while the level of a reduced form of DJ-1, one of the active forms of DJ-1, was decreased in SHSY-5Y cells treated with 6-OHDA or $\mathrm{H}_{2} \mathrm{O}_{2}$, PQQ increased the level of the reduced form of DJ-1. These results suggest that PQQ prevents oxidative stress-induced changes in oxidative status of DJ-1. Therefore, the neuroprotective effects of PQQ on oxidative stress-induced neuronal death may be at least in part involved in increased level of an active form of DJ-1.
\end{abstract}

Key words DJ-1; pyrroloquinoline quinone; oxidative stress; neurotoxity

Pyrroloquinoline quinone (PQQ) was identified as a redox cofactor of bacterial dehydrogenases ${ }^{1)}$ and later found to be present in various organisms, including mammals. ${ }^{2-6)} \mathrm{PQQ}$ has been shown to act as an anti-oxidant by scavenging superoxide radicals and to protect mitochondria from oxidative stress-induced damage. ${ }^{7)}$ PQQ has also been reported to prevent neuronal cell death in a rodent stroke model ${ }^{8-14)}$ and to prevent fibril formation of $\alpha$-synuclein in vitro. ${ }^{15)}$ The mechanism underlying PQQ activity, however, has not been elucidated.

$D J-1$ was identified by us as a novel oncogene ${ }^{16)}$ and later found to be a causative gene for a familial form Parkinson's disease (PD), PARK $7 .{ }^{17)}$ DJ-1 is a multi-functional protein and has been shown to play roles in anti-oxidative stress reaction, ${ }^{18-21)}$ transcriptional regulation ${ }^{22-26)}$ and chaperone reaction. ${ }^{27)}$ DJ-1 knockdown cells or DJ-1 knockout mice that had been treated with $\mathrm{H}_{2} \mathrm{O}_{2}$ or with several neurotoxins such as MPP+, 6-hydroxydopamine (6-OHDA), paraquat, and rotenone became highly susceptible to cell death, ${ }^{18-21,28-33)}$ and administration of DJ-1 into the substantia nigra of PD model rats that had been treated with 6OHDA protected the rat against dopaminergic cell death and decreased their locomotion defects. ${ }^{34)}$ It has also been shown that activity of mitochondrial complex 1 was reduced in DJ-1 knockdown cells ${ }^{19,35)}$ or in DJ-1 knockout mice, ${ }^{28,29)}$ suggesting that DJ-1 also regulates activity of mitochondrial complex I.

DJ-1 has three cysteines located at amino acid numbers 46, 53 and 106 (C46, C53 and C106, respectively). Of these three cysteines, $\mathrm{C} 106$ is the most susceptible to oxidation and is oxidized as $\mathrm{SOH}, \mathrm{SO}_{2} \mathrm{H}$ and $\mathrm{SO}_{3} \mathrm{H}$ forms. ${ }^{36)}$ Although oxidation at $\mathrm{C} 106$ is necessary for exerting activities of DJ-1, ${ }^{18-20,37)}$ it has been reported that highly oxidized DJ-1 at C106 lost its activity ${ }^{38)}$ and that abnormally oxidized forms of DJ-1 were observed in patients with sporadic forms of PD and Alzheimer's disease. ${ }^{39,40)}$

In this study, the expression levels and oxidative status at
C106 of DJ-1 were examined in human neuroblastoma cell line SH-SY5Y cells treated with $\mathrm{H}_{2} \mathrm{O}_{2}$ or 6-OHDA in the presence or absence of PQQ. The results showed that although the expression level of DJ-1 was not changed, the levels of reduced DJ-1 and oxidized DJ-1 at C106 with SOH were increased in cells treated with 6-OHDA and PQQ compared to the level in cells treated with 6-OHDA alone, suggesting that anti-oxidative activity of PQQ is, at least in part, catalyzed by DJ-1 activity.

\section{MATERIALS AND METHODS}

Materials PQQ was provided by Mitsubishi Gas Chemical Co., Inc. Vitamin C (ascorbic acid) and vitamin E ( $\alpha$-tocopherol) were purchased from Wako Pure Chemical, Japan.

Cells and Cell Viability Assay Human SH-SY5Y cells were cultured in Dulbecco's modified Eagle's medium supplemented with $10 \%$ calf serum. Cells in 96 -well plates (5000 cells/well) were cultured with or without various amounts of PQQ, vitamin $\mathrm{C}$ or vitamin $\mathrm{E}$ for $24 \mathrm{~h}$ and then treated with various amounts of $\mathrm{H}_{2} \mathrm{O}_{2}$ for $3 \mathrm{~h}$ or with 6OHDA for $48 \mathrm{~h}$. The cells were harvested and their viability was examined by a methyl thiazolyl tetrazolium (MTT) assay using a cell counting kit 8 (Dojindo).

Primary Neuronal Culture of the Ventral Mesencephalon Cultures of the rat mesencephalon were established according to methods described previously. ${ }^{41)}$ The ventral two-thirds of the mesencephalon was dissected from rat embryos on the 17-19th days of gestation. The dissected regions included dopaminergic neurons from the substantia nigra and the ventral tegmental area but not noradrenergic neurons from the locus ceruleus. Neurons were dissociated mechanically and plated out onto $0.1 \%$ polyethyleneiminecoated 96-well plates at a density of $2.5 \times 10^{6}$ cells/well. The cells were cultured in Dulbecco's modified Eagle's medium containing $10 \%$ fetal calf serum for $2 \mathrm{~d}$, and then in the same medium containing 2\% B-27 supplement (Invitrogen) and 
$2 \mathrm{mg} / \mathrm{ml}$ aphidicolin (Sigma) without fetal calf serum from the 3rd day onwards. The animals were treated in accordance with guidelines published in the NIH Guide for the Care and Use of Laboratory Animals.

To examine the effects of PQQ, vitamin $\mathrm{C}$ and vitamin $\mathrm{E}$ on oxidative stress-induced cell death, the cells were cultured in the presence or absence of $15 \mu \mathrm{M}$ of each compound for $24 \mathrm{~h}$ and then treated with $40 \mu \mathrm{m} 6$-OHDA for $24 \mathrm{~h}$ or with $300 \mu \mathrm{M} \mathrm{H} \mathrm{H}_{2} \mathrm{O}_{2}$ for $1.5 \mathrm{~h}$. Cell viability was then examined by an MTT assay.

Western Blotting To examine the expression of DJ-1 in SH-SY5Y cells that had been treated with $100 \mu \mathrm{M}$ 6-OHDA for $4 \mathrm{~h}$ in the presence or absence of $15 \mu \mathrm{M}$ PQQ, proteins were extracted from SH-SY5Y cells after incubation in a buffer containing $150 \mathrm{~mm} \mathrm{NaCl}, 1 \mathrm{~mm}$ EDTA, $20 \mathrm{~mm}$ Tris ( $\mathrm{pH} 8.0$ ), and $0.5 \%$ NP-40. Proteins were then separated on a $12.5 \%$ polyacrylamide gel containing SDS and subjected to Western blotting with a rabbit anti-DJ-1 (1/2000 dilution) or mouse anti-actin antibody (1/4000 dilution) (Chemicon). Proteins on the membrane were reacted with an IRDye 800 (Rockland) or Alexa680-conjugated secondary antibody (Molecular Probe) and visualized by using an infrared imaging system (Odyssey, LI-COR). For isoelectric focusing analysis, proteins were then separated in an isoelectric focusing gel of $\mathrm{pH} 5-8$ and subjected to Western blotting as described above. The rabbit anti-DJ-1 antibody was established by us as described previously. ${ }^{16)}$

Identification of Oxidative Status of C106 of DJ-1 by MALDI-TOF/TOF-MS Analysis SH-SY5Y cells were treated with $\mathrm{H}_{2} \mathrm{O}_{2}$ or 6-OHDA in the presence or absence of PQQ as described above. Cell extracts were prepared and immunoprecipitated with a rabbit anti-DJ-1 polyclonal antibody (final concentration of $4 \mu \mathrm{g} / \mathrm{ml}$ ), and immunoprecipitates were separated on a $12.5 \%$ polyacrylamide gel. After the gel had been stained with Coomassie brilliant blue (CBB), a band corresponding to DJ-1 was cut out, reduced, alkylated with a buffer containing iodoacetamide, and digested with trypsin. The peptide solutions were desalted, mixed with $\alpha$ cyano-4-hydroxycinnamic acid, and applied onto a target plate. MS/MS spectra of the C106-containing peptide spanning 100 - 122 amino acids were obtained by using an Ultraflex (Brucker Daltonics) in reflector mode and analyzed with flexanalysis software (Brucker Daltonics). Protein identification was carried out with Mascot software against the database of NIBI.

Binding of PQQ to the C106 Region by a Quartz Crystal Microbalance (QCM) Fixation of PQQ and DJ-1-binding compounds on a sensor chip of QCM (Affinix Q, Initium) was carried out as follows. In the case of compound $\mathrm{A}$, the sensor chip was incubated with $100 \mu \mathrm{l}$ of $5 \mathrm{~mm} \mathrm{3,3^{ \prime } -}$ dithiodipropionic acid for $1 \mathrm{~h}$ and then with $50 \mu \mathrm{l}$ each of $100 \mathrm{mg} / \mathrm{ml}$ 1-(3-dimethylaminopropyl)-3-ethylcarbodiimine hydrochloride (EDC) and $100 \mathrm{mg} / \mathrm{ml} N$-hydroxysuccinimide (NHS) for $20 \mathrm{~min}$. After washing the chip with $\mathrm{H}_{2} \mathrm{O}$, the chip was incubated with $4 \mu \mathrm{l}$ of $1 \mathrm{~mm}$ compound $\mathrm{A}$ dissolved in $\mathrm{H}_{2} \mathrm{O}$ for $1 \mathrm{~h}$. In the case of compound $\mathrm{C}$, the sensor chip was washed with a solution containing $\mathrm{H}_{2} \mathrm{O}_{2}$ and sulfonic acid (molar ratio $=1: 3$ ), and then it was incubated with $4 \mu \mathrm{l}$ of $1 \mathrm{~mm}$ compound $\mathrm{C}$ or PQQ dissolved in chloroform until the solution had evaporated. In the case of compound PQQ, the sensor chip was incubated with $20 \mathrm{~mm} 2$-aminoethanethiol for $1 \mathrm{~h}$, and then it was incubated with $4 \mu \mathrm{l}$ of $1 \mathrm{~mm}$ PQQ dissolved in $50 \mu \mathrm{l}$ each of $100 \mathrm{mg} / \mathrm{ml}$ EDC and $100 \mathrm{mg} / \mathrm{ml} \mathrm{NHS}$ for $20 \mathrm{~min}$. After washing the chip, it was incubated with $100 \mu \mathrm{l}$ of $1 \mathrm{~m}$ Tris- $\mathrm{HCl}$ ( $\mathrm{pH} 8.8$ ). To the sensor chips fixed with compounds in Affinix Q, $8 \mu \mathrm{l}$ of $1 \mathrm{mg} / \mathrm{ml}$ wild-type DJ1 was applied, and their frequency was measured according to the manufacturer's protocol.

Statistical Analysis Data are expressed as means \pm S.D. Statistical analyses were performed using analysis of variance (one-way ANOVA) followed by unpaired Student's $t$ test.

\section{RESULTS}

Effect of PQQ on Oxidative Stress-Induced Cell Death The effect of PQQ on cell viability was first examined. Human dopaminergic neuroblastoma cell line SH-SY5Y cells were incubated with various concentrations of PQQ for $24 \mathrm{~h}$ and cell viability was measured by an MTT assay (Fig. 1A). Although PQQ at concentrations up to $20 \mu \mathrm{M}$ had little effect on cell viability, PQQ at concentration of more than $30 \mu \mathrm{M}$ significantly reduced cell viability. We therefore used $15 \mu \mathrm{M}$ PQQ in this study. The effect of PQQ on oxidative stress-induced cell death was then examined. Vitamins $C$ and $\mathrm{E}$, well known anti-oxidants, were used as positive controls. SH-SY5Y cells were incubated with $15 \mu \mathrm{M}$ each of PQQ, vi-

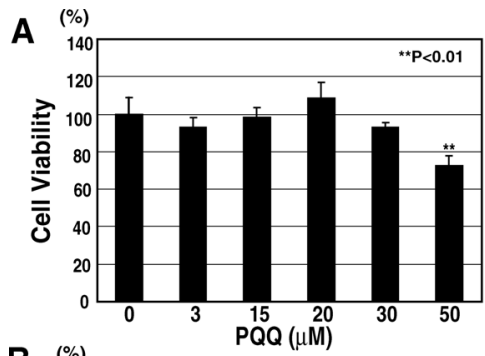

B
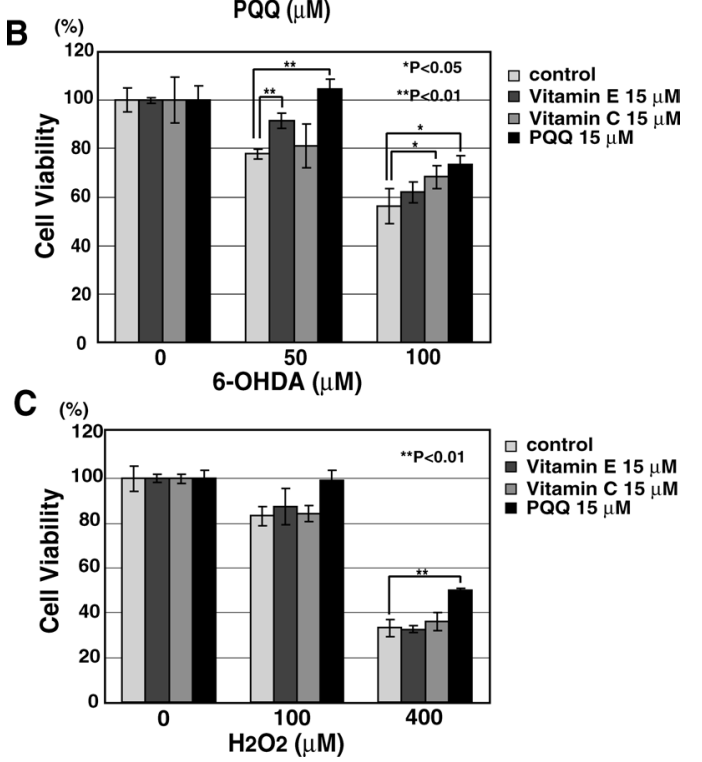

Fig. 1. Effect of PQQ on Oxidative Stress-Induced Death in SHSY-5Y Cells

(A) SH-SY5Y cells were pretreated with various concentrations of PQQ for $24 \mathrm{~h}$, and cell viability was measured by an MTT assay. $* * p<0.01 v s$. cell viability without PQQ. (B, C) SH-SY5Y cells were pretreated with $15 \mu \mathrm{M}$ of PQQ, vitamin C or vitamin E for $24 \mathrm{~h}$ and then treated with 6-OHDA for $48 \mathrm{~h}(\mathrm{~B})$ or with $\mathrm{H}_{2} \mathrm{O}_{2}$ for $3 \mathrm{~h}(\mathrm{C})$ and cell viability was measured by an MTT assay. Significance: $* p<0.05$, $* * p<0.01$. 
tamin $\mathrm{C}$ and vitamin $\mathrm{E}$ for $24 \mathrm{~h}$ and then treated with 6OHDA for $48 \mathrm{~h}$ or with $\mathrm{H}_{2} \mathrm{O}_{2}$ for $3 \mathrm{~h}$, and cell viability was measured by the MTT assay (Figs. 2B, C, respectively). Without PQQ, vitamin $\mathrm{C}$ and vitamin $\mathrm{E}$, cell death occurred in a dose-dependent manner. With PQQ, vitamin $\mathrm{C}$ and vitamin $\mathrm{E}$, on the other hand, cell death induced by addition of $\mathrm{H}_{2} \mathrm{O}_{2}$ or 6-OHDA was inhibited, and the level of inhibitory activity of PQQ was much higher than that of vitamin $\mathrm{C}$ and vitamin $\mathrm{E}$ at the concentration used.

Primary neuronal cells of the ventral mesencephalon were prepared from rat embryos on the 17-19th days of gestation, and cells were pretreated with compounds for $24 \mathrm{~h}$ and then treated with $300 \mu \mathrm{M} \mathrm{H}_{2} \mathrm{O}_{2}$ for $1.5 \mathrm{~h}$ or with $40 \mu \mathrm{M}$ 6OHDA for $24 \mathrm{~h}$. While neither vitamin $\mathrm{C}$ nor vitamin $\mathrm{E}$ showed significant protective activity, PQQ significantly abrogated cell death (Fig. 2A or B, respectively).

Effect of PQQ on the Expression and Oxidative Status of DJ-1 SH-SY5Y cells were cultured with $15 \mu \mathrm{M}$ PQQ for $24 \mathrm{~h}$ and then cultured with or without $100 \mu \mathrm{M}$ 6-OHDA for $48 \mathrm{~h}$. Protein extract was prepared from cells and analyzed by Western blotting with anti-DJ-1 and anti-actin antibodies, and the expression level of DJ-1 in cells was normalized against that of actin (Fig. 3A). The results showed that there was no change in DJ-1 expression in cells after treatment with PQQ.

Since the oxidative status of DJ-1 at C106 is important for its activity, proteins in cells were separated on two-dimension (2D) gels and subjected to Western blotting with an anti-DJ-1 antibody (Fig. 3B). Without PQQ and 6-OHDA treatment, major and minor spots with isoelectronic points of $\mathrm{pH} 6.2$ and 5.8, respectively, were observed, and a pattern similar to

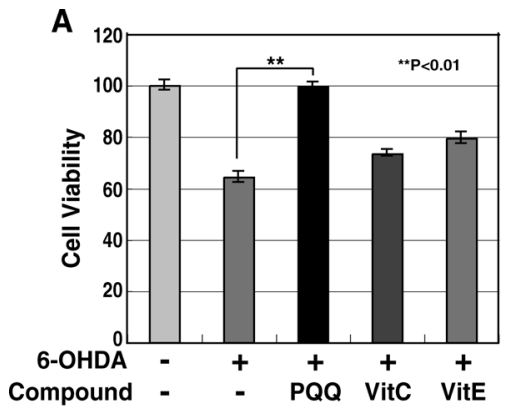

B

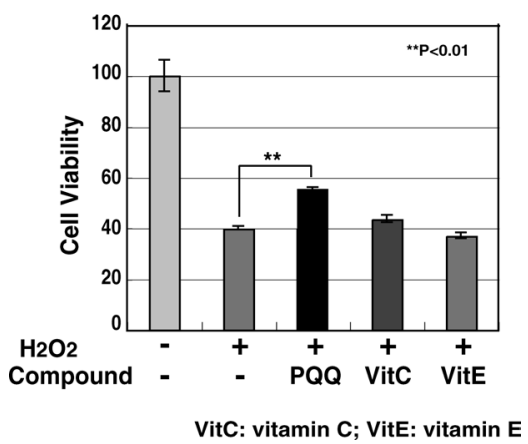

Fig. 2. Effect of PQQ on Oxidative Stress-Induced Death of Primary Neurons

Rat mesencephalic cultured neurons were pretreated with $15 \mu \mathrm{M}$ of PQQ, vitamin C or vitamin $\mathrm{E}$ for $24 \mathrm{~h}$ and then treated with $40 \mu \mathrm{m}$ 6-OHDA for $24 \mathrm{~h}$ (A) or with $300 \mu \mathrm{m}$ $\mathrm{H}_{2} \mathrm{O}_{2}$ for $1.5 \mathrm{~h}(\mathrm{~B})$ and cell viability was measured by an MTT assay. Significance: $* * p<0.01 v s$. cell viability with 6-OHDA or $\mathrm{H}_{2} \mathrm{O}_{2}$ in the absence of compounds. that without PQQ treatment was observed after cells treated with PQQ (Figs. 3B-a, B-b, respectively). After treatment of cells with 6-OHDA, on the other hand, a band with a more acidic point appeared and this band disappeared in cells treated with 6-OHDA and PQQ (Figs. 3B-c, B-d, respectively). These results suggest that PQQ prevents oxidation of DJ-1 that is induced by 6-OHDA.

To verify the oxidative status of DJ-1 precisely, SH-SY5Y cells were treated with 6-OHDA or with $\mathrm{H}_{2} \mathrm{O}_{2}$ and PQQ as described above. The cell extract was then immunoprecipitated with an anti-DJ-1 antibody and precipitates were separated on polyacrylamide gel. A protein band corresponding to DJ-1 was cut out after staining the gel, digested with trypsin, and subjected to MALDI-TOF/TOF-MS analysis (Fig. 4A). A segment containing $\mathrm{C} 106$ had seven peaks that correspond to reduced and oxidized $\mathrm{C} 106$ as $\mathrm{SOH}, \mathrm{SO}_{2} \mathrm{H}$ and $\mathrm{SO}_{3} \mathrm{H}$. Since some of cysteine residues that had been reduced and oxidized as $\mathrm{SOH}$ and $\mathrm{SO}_{2} \mathrm{H}$, but not as $\mathrm{SO}_{3} \mathrm{H}$, were modified with iodoacetamide, molecular weight 56 was added to molecular weight of C106-containing peptides with unmodified and modified forms (Fig. 4A).

Without $\mathrm{H}_{2} \mathrm{O}_{2}$ or 6-OHDA treatment, the reduced form of C106 was $90 \%$ of total forms (Fig. 4B). After treatment with 6-OHDA, the reduced form of C106 decreased to 75\%. Pretreatment with PQQ increased the reduced form of C106 to about $90 \%$, but pretreatment with vitamin $\mathrm{C}$ decreased the reduced from of $\mathrm{C} 106$ to $65 \%$ (Fig. 4B, left parts). After treatment with $\mathrm{H}_{2} \mathrm{O}_{2}$, on the other hand, the reduced form of C106 decreased to $42 \%$. Pretreatment with PQQ and with vitamin $\mathrm{C}$ increased the reduced form of $\mathrm{C} 106$ to about $76 \%$ and to $46 \%$, respectively (Fig. 4B, right parts). The oxidized form of $\mathrm{C} 106$ as $\mathrm{SO}_{3} \mathrm{H}$ that had appeared after treatment with $\mathrm{H}_{2} \mathrm{O}_{2}$ also decreased in cells pretreated with PQQ. These results indicate that DJ-1 at least with the reduced form of

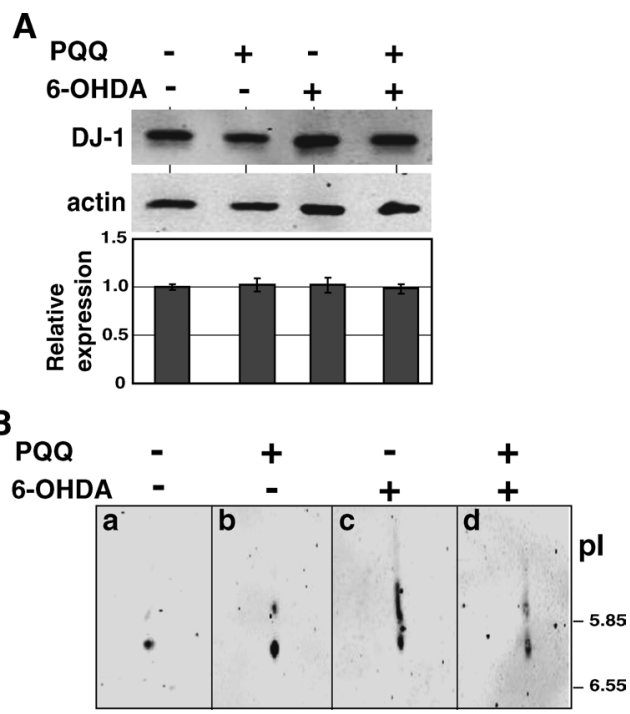

Fig. 3. Abrogation of Superfluous Oxidation of DJ-1 at C106 by PQQ in SHSY-5Y Cells

(A) SH-SY5Y cells were cultured with or without $15 \mu \mathrm{M}$ of PQQ for $24 \mathrm{~h}$ and then treated with $100 \mu \mathrm{m}$ 6-OHDA for $4 \mathrm{~h}$. Cell extracts were then prepared and analyzed by Western blotting with anti-DJ-1 and anti-actin antibodies as described in Materials and Methods. After quantification of intensities of bands corresponding to DJ-1 and actin using an infrared imaging system (Odyssey, LI-COR), relative expression (DJ-1/actin) was determined. (B) SH-SY5Y cells were treated with PQQ and 6-OHDA as described in the legend of Fig. 3A, proteins in cell extracts were separated on 2D gels and subjected to Western blotting with anti-DJ-1 and anti-actin antibodies as described in Materials and Methods. 

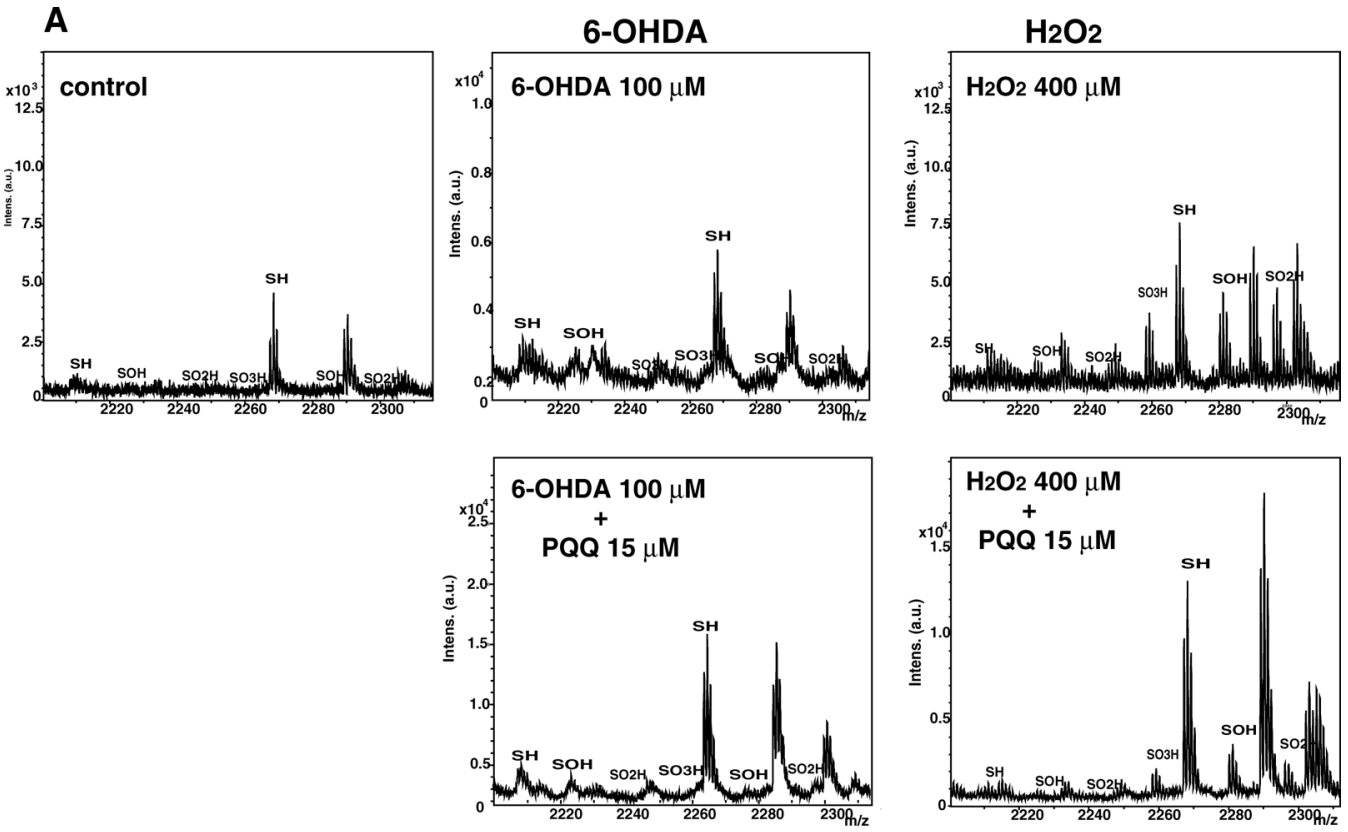

B
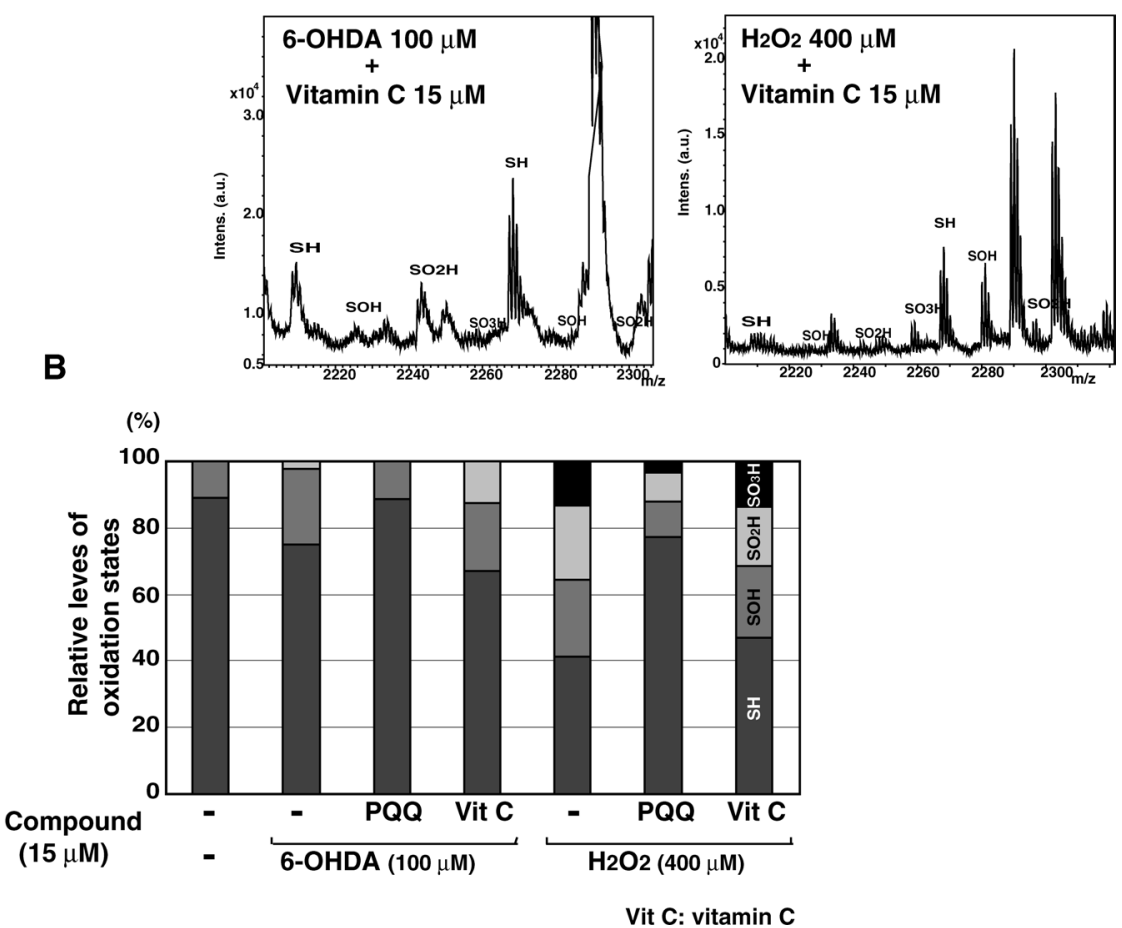

Fig. 4. Effect of PQQ on the Oxidative Status of DJ-1 in SHSY-5Y Cells

(A) SH-SY $5 \mathrm{Y}$ cells were pretreated with $15 \mu_{\mathrm{M}}$ of PQQ or vitamin $\mathrm{C}$ for $24 \mathrm{~h}$ and then treated with $100 \mu \mathrm{M} 6-\mathrm{OHDA}$ for $4 \mathrm{~h}$ or with $400 \mu \mathrm{M} \mathrm{H}_{2} \mathrm{O}_{2}$ for $90 \mathrm{~min}$. Cell extracts were immunoprecipitated with an anti-DJ-1 antibody and the precipitates were separated on a $12 \%$ polyacrylamide gel. A stained band corresponding to DJ-1 was analyzed by MALDITOF/TOF-MS as described in Materials and Methods. Since cysteine residues that had been reduced and oxidized $\mathrm{C}_{106}$ as $\mathrm{SOH}_{\text {and }} \mathrm{SO}_{2} \mathrm{H}$, but not as $\mathrm{SO}_{3} \mathrm{H}$, were modified with iodoacetamide, a molecular weight of 56 was added to the molecular weights of C106-containing peptides spanning 100 - 122 amino acids. (B) Ratios of reduced and oxidized forms of $\mathrm{C} 106$ are presented.

$\mathrm{C} 106$ is an active form and that $\mathrm{DJ}-1$ with the $\mathrm{SO}_{3} \mathrm{H}$ form of $\mathrm{C} 106$ is an inactive form. It is therefore thought that PQQ prevents superfluous oxidation of DJ-1.

No Binding of PQQ to DJ-1 We identified compounds that bind to the $\mathrm{C} 106$ region and found that these compounds prevented oxidative stress-induced death of cells. ${ }^{42)}$ We therefore examined whether PQQ also binds to DJ-1 by using a quartz crystal microbalance in which $\mathrm{PQQ}$, compound $\mathrm{A}$ or compound $\mathrm{C}$ was fixed on a sensor chip and recombinant wild-type DJ-1 was applied. In this case, compounds A and $\mathrm{C}$ were used as DJ-1-binding and non-binding compounds, respectively. As shown in Fig. 5, compound A but not $\mathrm{C}$ bound to DJ-1, and PQQ hardly bound to DJ-1.

\section{DISCUSSION}

6-OHDA is a neurotoxin that compromises mitochondrial complex I, resulting in production of reactive oxygen species 

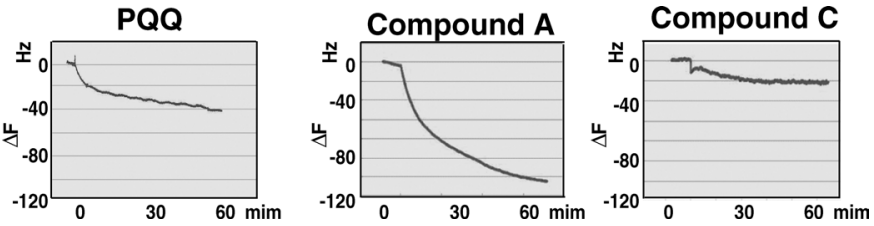

Fig. 5. No Binding of PQQ to DJ-1

Binding of PQQ to DJ-1 was examined by using a quartz crystal microbalance as described in Materials and Methods. Compounds A and C were used as DJ-1-binding and -nonbinding compounds, respectively. $\Delta F$ indicates decreased frequency of a sensor chip.

(ROS) such as superoxide, hydroxyl radical and $\mathrm{H}_{2} \mathrm{O}_{2}$. The ROS produced then attacks mitochondria, resulting in the damage in mitochondrial complex I. Reactive nitrogen species such as nitrogen oxide (NO) and peroxynitrite also cause damage to cells, including neuronal cells. It has been reported that PQQ scavenges superoxide anion and hydroxyl radicals in an in vitro system ${ }^{7)}$ and that PQQ suppresses peroxynitrite formation and NO-induced neurotoxity. ${ }^{9)}$ The molecular mechanism underlying the preventive effect of PQQ, however, has not been elucidated. In this study, we showed that PQQ prevented $\mathrm{H}_{2} \mathrm{O}_{2}$ - and 6-OHDA-induced death of the dopaminergic neuroblastoma cell line SH-SY5Y and primary rat neurons and that its preventive effect was stronger than that of vitamins $\mathrm{C}$ and $\mathrm{E}$, well-known antioxidants, at the concentration used in this study. Under these conditions in which SH-SY5Y cells were treated with $\mathrm{H}_{2} \mathrm{O}_{2}$ or 6-OHDA in the presence or absence of PQQ, we found that the level of oxidation of DJ-1 at C106 was reduced by PQQ addition compared to that without PQQ, though the expression level and localization (data not shown) of DJ-1 were not changed. Although it is not clear which forms of oxidized C106, SH (reduced), $\mathrm{SOH}, \mathrm{SO}_{2} \mathrm{H}$ and $\mathrm{SO}_{3} \mathrm{H}$, of DJ-1 are active forms, the level of $\mathrm{C} 106$ with SH was clearly changed. It has been reported that DJ-1 has a chaperone activity inhibiting aggregation of $\alpha$-synuclein in vitro and that DJ-1 at C106 with $\mathrm{SO}_{2} \mathrm{H}$ is the active form in this reaction. ${ }^{38)}$ In SH-SY5Y cells treated with $\mathrm{H}_{2} \mathrm{O}_{2}$ or 6-OHDA, however, the level of $\mathrm{C} 106$ with $\mathrm{SO}_{2} \mathrm{H}$ increased, suggesting that other forms such as $\mathrm{SH}$ and $\mathrm{SOH}$ forms of $\mathrm{C} 106$ are active. In cells treated with $\mathrm{H}_{2} \mathrm{O}_{2}$, the level of $\mathrm{C} 106$ with $\mathrm{SO}_{3} \mathrm{H}$ increased and then decreased after addition of PQQ. Since DJ-1 at C106 with $\mathrm{SO}_{3} \mathrm{H}$ was inactive in terms of chaperone activity ${ }^{38)}$ and a highly oxidized form of DJ-1, perhaps DJ-1 at C106 with $\mathrm{SO}_{3} \mathrm{H}$, was observed in brains of patients with Parkinson's disease and Alzheimer's disease, ${ }^{39,40)}$ DJ-1 at C106 with $\mathrm{SO}_{3} \mathrm{H}$ is thought to be inactive against oxidative stress-induced cell death.

The level of DJ-1 at $\mathrm{C} 106$ with $\mathrm{SO}_{2} \mathrm{H}$ was increased after SH-SY5Y cells were treated with 6-OHDA and vitamin $\mathrm{C}$ compared to that in cells treated with 6-OHDA alone (Fig. $4)$. This phenomenon was different from that in cells treated with 6-OHDA and PQQ, though both PQQ and vitamin $\mathrm{C}$ exerted protective effects against 6-OHDA-induced cell death (Fig. 1), suggesting that there is a distinct mechanism of anti-oxidative stress function between PQQ and vitamin $\mathrm{C}$.

The cysteine residue at amino acid number $106(\mathrm{C} 106)$ is an essential amino acid for DJ-1 to exert its activity. ${ }^{18-20,37)}$ We have identified compounds that bind to the $\mathrm{C} 106$ region of DJ-1, and these compounds prevented oxidative stress-in- duced neuronal cell death and movement defect in cultured cells and in 6-OHDA-injedcted PD rat models. ${ }^{42}$ ) These compounds A (UCP0045037) and B (UCP0054278), which are novel and uncharacterized compounds, respectively, prevent superficial oxidation of $\mathrm{C} 106$ by binding to the $\mathrm{C} 106$ region, thereby keeping active forms of DJ-1. Of DJ-1-binding compounds, compound A was used as a positive control in a DJ1-binding experiment of PQQ (Fig. 5). Since PQQ was found not to bind to DJ-1, there are at least two possibilities. One possibility is that elimination of ROS by PQQ leads to prevention of DJ-1 oxidation. Another possibility is that PQQ affects some signaling pathways that regulate oxidation of DJ-1. Although pathways in oxidative stress reactions that are affected by PQQ have not been identified, it has recently been reported that PQQ activated ras signaling pathways such as the Raf/ERK pathway, leading to stimulation of growth of ras-transformed NIH3T3 but not untransformed NIH3T3 cells. ${ }^{43)}$ Since $D J-1$ was identified as an oncogene in cooperation with activated ras, ${ }^{16)}$ factors involved in ras signaling pathways may affect the oxidation status of DJ-1.

Acknowledgments We thank Yoko Misawa and Kiyomi Takaya for their technical assistance. We also thank Kazuko Takahashi-Niki for preparation of rat primary neurons. This work was supported by Grants-in-Aid from the Ministry of Education, Culture, Sports, Science and Technology and by the Program for Promotion of Fundamental Studies in Health Sciences of the National Institute of Biomedical Innovation (NIBIO) in Japan.

\section{REFERENCES}

1) Salisbury S. A., Forrest H. S., Cruse W. B., Kennard O., Nature (London), 280, 843-844 (1979).

2) Gallop P. M., Paz M. A., Flückiger R., Kagan H. M., Trends Biochem. Sci., 14, 343-346 (1989).

3) Goodwin P. M., Anthony C., Adv. Microb. Physiol., 40, 1-80 (1998).

4) Smidt C. R., Steinberg F. M., Rucker R. B., Proc. Soc. Exp. Biol. Med., 197, 19-26 (1991).

5) Bishop A, Gallop P. M., Karnovsky M. L., Nutr. Rev., 56, 287-293 (1998).

6) McIntire W. S., Annu. Rev. Nutr., 18, 145-177 (1998).

7) Misra H. S., Khairnar N. P., Barik A., Indira Priyadarsini K., Mohan H., Apte S. K., FEBS Lett., 578, 26-30 (2004).

8) Jensen F. E., Gardner G. J., Williams A. P., Gallop P. M., Aizenman E., Rosenberg P. A., Neuroscience, 62, 399-406 (1994).

9) Zhang Y., Rosenberg P. A., Eur. J. Neurosci., 16, 1015-1024 (2002).

10) He K., Nukada H., Urakami T., Murphy M. P., Biochem. Pharmacol., 65, 67-74 (2003).

11) Zhang Y., Feustel P. J., Kimelberg H. K., Brain Res., 1094, 200-206 (2006).

12) Hara H., Hiramatsu H., Adachi T., Neurochem. Res., 32, 489-495 (2007).

13) Tao R., Karliner J. S., Simonis U., Zheng J., Zhang J., Honbo N., Alano C. C., Biochem. Biophys. Res. Commun., 363, 257-262 (2007).

14) Ohwada K,. Takeda H., Yamazaki M., Isogai H., Nakano M., Shimomura M., Fukui K., Urano S., J. Clin. Biochem. Nutr., 42, 29-34 (2008).

15) Kobayashi M., Kim J., Kobayashi N., Han S., Nakamura C., Ikebukuro K., Sode K., Biochem. Biophys. Res. Commun., 349, 1139-1144 (2006).

16) Nagakubo D., Taira T., Kitaura H., Ikeda M., Tamai K., Iguchi-Ariga S. M. M., Ariga H., Biochem. Biophys. Res. Commum., 31, 509-513 (1997).

17) Bonifati V., Rizzu P., van Baren M. J., Schaap O., Breedveld G. J., Krieger E., Dekker M. C., Squitieri F., Ibanez P., Joosse M., van Dongen J. W., Vanacore N., van Swieten J. C., Brice A., Meco G., van 
Duijn C. M., Oostra B. A., Heutink P., Science, 299, 256-259 (2003).

18) Taira T., Saito Y., Niki T., Iguchi-Ariga S. M. M., Takahashi K., Ariga H., EMBO Rep., 5, 213-218 (2004).

19) Canet-Aviles R. M., Wilson M. A., Miller D. W., Ahmad R., McLendon C., Bandyopadhyay S., Baptista M. J., Ringe D., Petsko G. A., Cookson M. R., Proc. Natl. Acad. Sci. U.S.A., 101, 9103-9108 (2004).

20) Martinat C., Shendelman S., Jonason A., Leete T., Beal M. F., Yang L., Floss T., Abeliovich A., PLoS Biol., 2, e327 (2004)

21) Yokota T., Sugawara K., Ito K., Takahashi R., Ariga H., Mizusawa H., Biochem. Biophys. Res. Commun., 312, 1342-1348 (2003).

22) Takahashi K., Taira T., Niki T., Seino C., Iguchi-Ariga S. M. M., Ariga H., J. Biol. Chem., 276, 37556-37563 (2001).

23) Niki T., Takahashi-Niki K., Taira T., Iguchi-Ariga S. M. M., Ariga H., Mol. Cancer Res., 1, 247-261 (2003).

24) Shinbo Y., Taira T., Niki T., Iguchi-Ariga S. M. M., Ariga H., Int. J. Oncol., 26, 641-648 (2005).

25) Xu J., Zhong N., Wang H., Elias J. E., Kim C. Y., Woldman I., Pifl C., Gygi S. P., Geula C., Yankner B. A., Hum. Mol. Genet., 14, 12311241 (2005).

26) Zhong N., Kim C. Y., Rizzu P., Geula C., Porter D. R., Pothos E. N., Squitieri F., Heutink P., Xu J., J. Biol. Chem., 281, 20940-20948 (2006).

27) Shendelman S., Jonason A., Martinat C., Leete T., Abeliovich A., PLoS Biol., 2, e362 (2004).

28) Goldberg M. S., Pisani A., Haburcak M., Vortherms T. A., Kitada T., Costa C., Tong Y., Martella G., Tscherter A., Martins A., Bernardi G., Roth B. L., Pothos E. N., Calabresi P., Shen J., Neuron, 45, 489-496 (2005).

29) Kim R. H., Smith P. D., Aleyasin H., Hayley S., Mount M. P., Pownall S., Wakeham A., You-Ten A. J., Kalia S. K., Horne P., Westaway D., Lozano A. M., Anisman H., Park D. S., Mak T. W., Proc. Natl. Acad. Sci. U.S.A., 102, 5215-5220 (2005).

30) Chen L., Cagniard B., Mathews T., Jones S., Koh H. C., Ding Y., Carvey P.M., Ling Z., Kang U. J., Zhuang X., J. Biol. Chem., 280, $21418-21426$ (2005)

31) Manning-Bo A. B., Caudle W. M., Perez X. A., Reaney S. H., Paletzki R., Isla M. Z., Chou V. P., McCormack A. L., Miller G. W., Langston J. W., Gerfen C. R., Dimonte D. A., Neurobiol. Dis., 27, 141-150
(2007).

32) Andres-Mateos E., Perier C., Zhang L., Blanchard-Fillion B., Greco T. M., Thomas B., Ko H. S., Sasaki M., Ischiropoulos H., Przedborski S., Dawson T. M., Dawson V. L., Proc. Natl. Acad. Sci. U.S.A., 104 14807-14812 (2007).

33) Chandran J. S., Lin X., Zapata A., Höke A., Shimoji M., Moore S. O., Galloway M. P., Laird F. M., Wong P. C., Price D. L., Bailey K. R., Crawley J. N., Shippenberg T., Cai H., Neurobiol. Dis., 29, 505-514 (2008).

34) Inden M., Taira T., Kitamura Y., Yanagida T., Tsuchiya D., Takata K., Yanagisawa D., Nishimura K., Taniguchi T., Kiso Y., Yoshimoto K., Agatsuma T., Koide-Yoshida S., Iguchi-Ariga S. M. M., Shimohama S., Ariga H., Neurobiol. Dis.., 24, 144-158 (2006).

35) Ooe H,. Taira T., Iguchi-Ariga S. M. M., Ariga H., Toxicol. Sci., 88, $114-126$ (2005)

36) Kinumi T., Kimata J., Taira T., Ariga H., Niki E., Biochem. Biophys Res. Commum., 317, 722-728 (2004).

37) Takahashi-Niki K., Niki T., Taira T., Iguchi-Ariga S. M. M., Ariga H., Biochem. Biophys. Res. Commun., 320, 389-397 (2004).

38) Zhou W., Zhu M., Wilson M. A., Petsko G. A., Fink A. L., J. Mol. Biol., 356, 1036-1048 (2006).

39) Bandopadhyay R., Kingsbury A. E., Cookson M. R., Reid A. R., Evans I. M., Hope A. D., Pittman A. M., Lashley T., Canet-Aviles R., Miller D. W., McLendon C., Strand C., Leonard A. J., Abou-Sleiman P. M., Healy D. G., Ariga H., Wood N. W., de Silva R., Revesz T., Hardy J. A., Lees A. J., Brain, 127, 420-430 (2004).

40) Choi J., Sullards M. C., Olzmann J. A., Rees H. D., Weintraub S. T., Bostwick D. E., Gearing M., Levey A. I., Chin L.-S., Li L., J. Biol. Chem., 281, 10816-10824 (2006).

41) Sawada H., Kohno R., Kihara T., Izumi Y., Sakka N., Ibi M., Nakanishi M., Nakamizo T., Yamakawa K., Shibasaki H., Yamamoto N., Akaike A., Inden M., Kitamura Y., Taniguchi T., Shimohama S., J. Biol. Chem., 279, 10710-10719 (2004).

42) Miyazaki S., Yanagida T., Nunome K., Ishikawa S., Inden M., Kitamura K., Nakagawa S., Taira T., Hirota K., Niwa M., Iguchi-Ariga S. M. M., Ariga H., J. Neurochem., 105, 2418-2434 (2008).

43) Kumazawa T., Hiwasa T., Takiguchi M., Suzuki O., Sato K., Int. J. Mol. Med., 19, 765-770 (2007). 